\title{
Core area and centre of activity of maned wolves, Chrysocyon brachyurus (Illiger) (Mammalia, Canidae), submitted to supplemental feeding
}

\author{
Joaquim de Araújo Silva \& Sônia Aparecida Talamoni
}

Grupo de Conservação, Ecologia e Comportamento Animal, Programa de Pós-graduação em Zoologia de Vertebrados, Pontifícia Universidade Católica de Minas Gerais. Caixa Postal 2686, 30535-610 Belo Horizonte, Minas Gerais, Brasil. E-mail:quincass@hotmail.com, talamoni@pucminas.br

\begin{abstract}
Based on the finding of remains (tracks, scats, and hairs), an analysis was made of the core area and centre of activity of maned wolves, Chrysocyon brachyurus (IIliger, 1815), living in a private natural reserve in which ecotourism activities are developed and these animals are daily fed bovine meat. A total of 465 samples of remains were recorded. Using the fixed kernel method, the area encompassing all samples recorded was estimated at $25.7 \mathrm{~km}^{2}$, yet $50 \%$ of all samples were found in an area of only $1.5 \mathrm{~km}^{2}$, representing $5.8 \%$ of the total area covered. For estimating the core area of the animals, the frequency of occurrence of the samples was determined by superimposing a 50 x $50 \mathrm{~m}$ cell grid over a map of the area encompassing all recorded occurrences. Based on the cells containing more than six occurrences, the animals' core area was $0.99 \mathrm{~km}^{2}$, which included the place where the animals are fed. The centre of activity was located only $0.50 \mathrm{~km}$ from this place. The high negative correlation $(r=-0.93, p<0.05)$ between the densities of the recorded occurrences and the distances from these to the sanctuary indicates that the core area and centre of activity are conditioned by artificial feeding. KEY WORDS. Centre of activity, ecotourism activities, maned wolves, RPPN Serra do Caraça.
\end{abstract}

RESUMO. A área central e o centro de atividade de lobos-guará, Chrysocyon brachyurus (Illiger, 1815), foram determinados através de seus vestígios (fezes, pegadas e pêlos) em uma reserva natural particular, onde esses animais estão sujeitos à alimentação artificial e sofrem influência de atividades turísticas. No total, foram registrados 465 vestígios, sendo que $65,8 \%$ corresponderam à estação seca. Através do método Kernel fixo, a área compreendida por todos os vestígios foi de $25,7 \mathrm{~km}^{2}$, sendo que $50 \%$ encontravam-se em uma área de apenas $1,5 \mathrm{~km}^{2}$, o que representou $5,8 \%$ do total da área amostrada. A área central de atividade dos animais foi obtida pelo cálculo da freqüência dos registros dos vestígios através da sobreposição de uma quadrícula subdividida em células de 50 × $50 \mathrm{~m}$ sobre a área que abrangia todos os registros. Considerando as células com mais de seis registros a área central de atividade atribuída aos animais foi de 0,99 $\mathrm{km}^{2}$, o que abrangeu a sede da reserva onde os animais são alimentados. O centro de atividade localizou-se somente a 0,50 km da sede. A alta correlação negativa $(r=-0,93, p<0,05)$ obtida entre as densidades dos registros e suas distâncias até a sede da reserva indicaram que o centro de atividade e o tamanho da área de maior intensidade de uso são condicionados pela alimentação artificial.

PALAVRAS CHAVE. Centro de atividade, área central, atividades ecoturísticas, lobo-guará, RPPN Serra do Caraça.

Usually, home ranges comprise heterogeneous areas determined by physical and biological factors, which explain the disproportionate use of space by animals. Studies on various species show that, for a number of environment-related reasons, certain portions within the home range are more frequently used than others (Adams \& Davis 1967, van Ballenberghe \& Peek 1971, Metzgar 1973, Inglis et al. 1979, Dixon \& Chapman 1980, Georgit 1980, Springer 1982, Konecny 1989, Crawshaw \& Quigley 1989, Macdonald \& Courtenay 1996). Area of more intensive use have been conceived as the core area of the home range of the animal and may be related to the greater availability of food resources and refuges (BURT 1943, KaUfMANN 1962, Samuel et al. 1985 Samuel \& Garton 1987).

The areas more frequently used by an animal can be determined from the centre of activity (TANAKA 1980). This concept was used by HAYNe (1949), who described the centre of activity as being the arithmetic mean centre of all points of capture of an animal. A new method for calculating the centre of activity, based on the harmonic mean of an areal distribution, was subsequently proposed by DiXON \& CHAPMAN (1980). 
The centre of activity is located within the area of greater activity of the animals. Identifying these areas is of fundamental importance for understanding the biology of many species, including the interaction between individuals and between these and the environment.

The purpose of this study was to determine whether the size of the core area and location of the centre of activity of maned wolves, Chrysocyon brachyurus (Illiger, 1815), living in a private natural reserve are influenced by anthropic activities, considering that, for more than twenty years now, these animals have been fed on bovine meat and have grown accustomed to the presence of humans.

\section{MATERIAL AND METHODS}

\section{Study area}

The study was conducted in the Serra do Caraça Private Natural Heritage Reserve $\left(20^{\circ} 05^{\prime} S, 43^{\circ} 29^{\prime} W\right)$, located in the Minas Gerais State, South-eastern Brazil. The reserve has an area of $10,187.89 \mathrm{ha}$, and is situated in the southern portion of the Espinhaço Mountain range. This orographic system is represented by a mountainous complex that delimitates a zone of contact between the "Cerrado" (savannas) and the Atlantic Forest, in its southern portion, and transition zones of "Cerrado", Atlantic Forest, and "Caatinga" (tropical deciduous forest), in its central and northern edges (Giulietti \& Pirani 1988, GiulietTr et al. 1997). The reserve comprises three main floristic formations represented by seasonal semideciduous forests, "campos de altitude" (high altitude grasslands), and "campos rupestres" (rocky grasslands), which occurs in elevations between 850 and 2,072 $\mathrm{m}$. Climate in this region presents a rainy summer (October-March) and a dry winter (April-September). "Campos rupestres" consist of grasslands surrounded by rocky outcrops, as well as shrubs and small trees. Vegetation patches in different stages of ecological succession are present in the region, as a consequence of timber extraction and the "slash-and-burn" practice used in the past. The reserve represents a rich artistic, cultural and historical heritage resulting from over two centuries of human occupation (ANDrade 2000).

\section{Data collection and analysis}

The maned wolves were monitored through signs left by them in the environment (CHILDs \& CoLvin 1998). Among these, scats, tracks and hairs were used for analysis. The material was collected in an area with a $7 \mathrm{~km}$ radius, within altitudes ranging from 750 to $1500 \mathrm{~m}$, with the point of origin being the sanctuary, where bovine meat were daily delivered to the maned wolves. Between October, 2000 and September 2001, active search campaigns were conducted in all of the reserve's main and adjacent trails, in exposed-soil and rock outcrop areas, and on sand banks on the margins of water courses. An extent of approximately $30 \mathrm{~km}$ was covered each month. The animal's tracks were identified by their size and shape, the hairs by their colour, texture and size, and the scats by their morphological appearance and odour, associated with the substrate for deposition (CHILDs \& Colvin 1998).

Records were made of the geographical coordinates of all locations where samples were found. The scats and hairs were individually collected in plastic and paper bags, respectively, and the tracks erased. To ensure independence between samples, each location of the study area was sampled only once each month (Swihart \& S Lade 1985). During the same period, for three consecutive nights, small plastic beads $(2.73 \pm 0.15 \mathrm{~mm}$ in diameter) were used as scat markers (RANDOLF 1977, KRUUK 1978). The beads were mixed with the meat fed to the animals. A different bead color was used for each month sampled.

The area comprising all occurrences and the density $(25$, $50,75,90$ and $100 \%$ ) of the occurrences were estimated by the fixed Kernel method (WORTON 1989), using the Home Ranger software program (Hovey 1999). To determine the core area of the maned wolves, the frequency of occurrence was calculated by superimposing a $50 \times 50 \mathrm{~m}$ cell grid over a map of the area encompassing all occurrences, using the Leontop software program. The area corresponding to the grid cells containing the highest number of occurrences was then calculated by the minimum convex polygon method (MCP) (100\%) (МонR 1947).

The bead-marked scat samples collected allowed an estimate of the minimum area of activity of the animals, using the minimum convex polygon method (MCP) (100\%) (MoHr, 1947) and the Leontop software program. The centre of activity was determined by calculating the arithmetic mean centre (HAYNe 1949) and the harmonic mean centre (DIXON \& CHAPMAN 1980). To confirm whether the movement of the animals was influenced by the daily supply of meat, a Pearson's test (r) (ZAR 1999) was used for correlating the densities of the occurrences obtained by the fixed Kernel method (Hovey 1999) with the mean distances from the sites of the recorded occurrences to the sanctuary.

\section{RESULTS}

A total of 465 samples of remains were analysed, of which 306 (65.8\%) were collected in the dry season and 159 (34.2\%) in the rainy season. The average number of samples/ month was $38.8 \pm 19.2$. Among the items collected, scats were the most frequent $(n=223)$, followed by tracks $(n=182)$ and hairs $(\mathrm{n}=60)$. Of all scat samples, $82.9 \%$ were deposited on rocks, $11.6 \%$ on heaps of crushed rock, $2.2 \%$ on trails, $1.8 \%$ on an asphalt road, and $0.9 \%$ on top of termite mounds. Maned wolf tracks were found in exposed-soil trails used by visitors, as well as in less frequented footpaths adjacent to the main trails. Most of the tracks $(84.0 \%)$ were in predominantly sandy soil, $13.8 \%$ in sandy-clayey soil, and $2.2 \%$ in wet areas and sand piles. Hairs, in turn, were always found in clumps attached to the reserve's barbed-wire fences, which revealed the animals' habit of passing through these obstacles. 
The area encompassing $100 \%$ of the recorded samples was $25.7 \mathrm{~km}^{2}$ (Fig. 1). The sample occurrence pattern tended toward central, aggregated distribution (50\% of the occurrences were recorded in an area of $1.5 \mathrm{~km}^{2}$ ) (Fig. 1). Of the grid cells (241 cells) superimposed on the map of the area comprising all occurrences, $76.8 \%$ had only 1 or 2 occurrences, and only $2.0 \%$ contained 6 to 15 occurrences (Fig. 2). Considering these latter cells only, the core area attributed to the animals was $0.99 \mathrm{~km}^{2}$ (Fig. 3), corresponding to $3.8 \%$ of the total area sampled. Nine scats samples containing the beads were found, representing $4.0 \%$ of the total samples collected. Based on these findings, the minimum area (MCP) used by the animals was $0.93 \mathrm{~km}^{2}$ (Fig. 3).

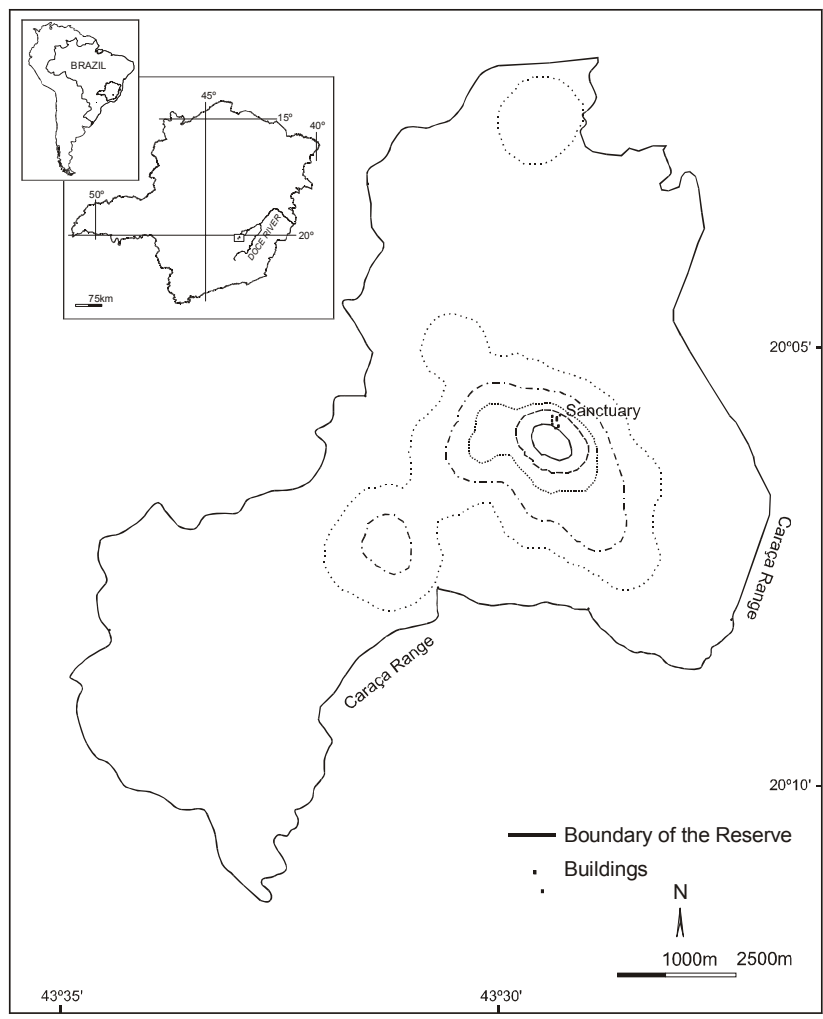

Figure 1. Areas encompassing $100,95,75,50$ and $25 \%$ of the recorded samples (scats, tracks and hairs), estimated by the fixed Kernel method.

The coordinates of the mean arithmetic centre were close to those of the mean harmonic centre, the distance between them being $0.14 \mathrm{~km}$ and their distances to the sanctuary being $0.50 \mathrm{~km}$ and $0.51 \mathrm{~km}$, respectively (Fig. 3). A highly significant negative correlation was recorded between the densities of the occurrences and the mean distances from these to the sanctuary $(\mathrm{r}=-0.93, \mathrm{p}<0.05)$ (Fig. 4).

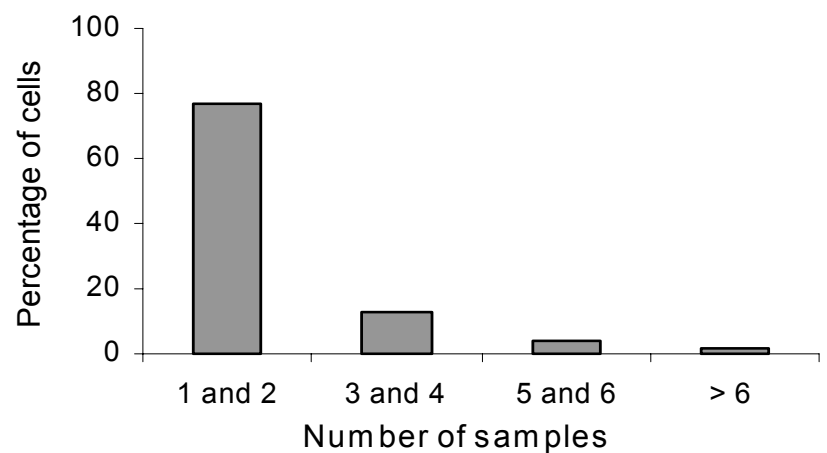

Figure 2. Percentage of cells $(n=241)$ containing a number of signs (scats, tracks and hairs) left by the maned wolf at Serra do Caraça Reserve, Minas Gerais State, South-eastern Brazil.

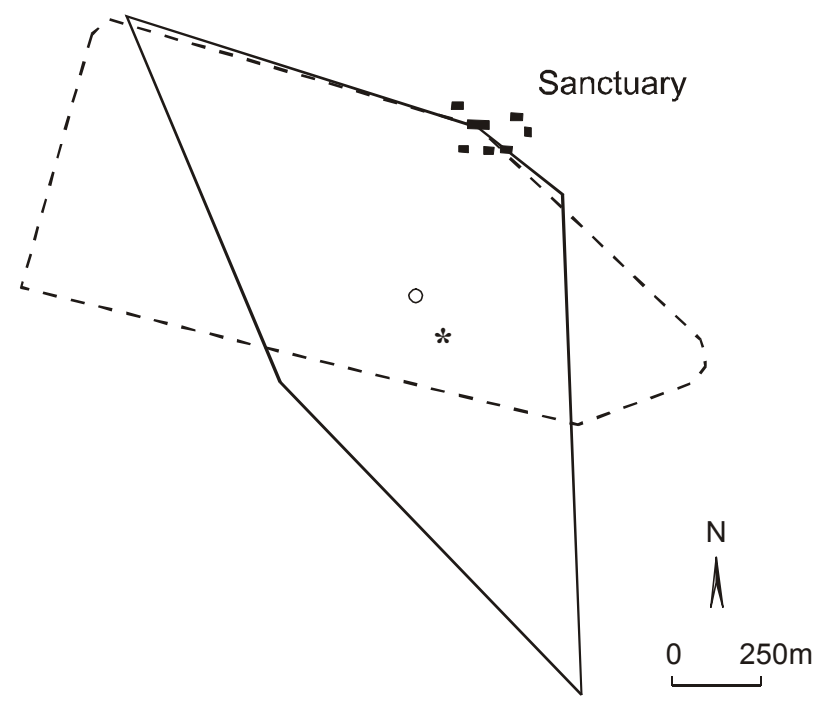

Figure 3. The core area of the maned wolves (dashed line) and minimum area (MPC) (100\%) (continuous line) obtained from the bead-marked scat samples. The " $\mathrm{O}$ " is the mean centre arithmetic and the "*" is the mean centre harmonic.

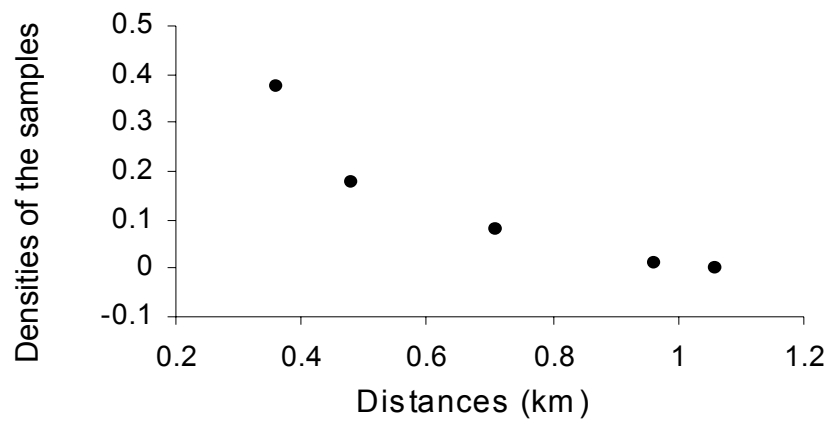

Figure 4. Scatter diagram of density of the samples, obtained by the fixed kernel method, and the mean distances from these to the Sanctuary.

Revista Brasileira de Zoologia 21 (2): 391-395, junho 2004 


\section{DISCUSSION}

The higher incidence of occurrences recorded in the dry season was probably due to the fact that scats deposited on rock outcrops are easily washed away by the rain (DiETz 1984, ArAGONA $\&$ SETZ 2001). The same is true of tracks, which, during the rainy season, are quickly erased, particularly in sandy soils, where a higher incidence of tracks was obtained. In areas with less availability of substrates, such as rocks, exposed soil, trails and sand banks, the percentage of occurrences may have been underestimated. In addition, the remains found at locations farther than $5 \mathrm{~km}$ from the sanctuary may not belong to individuals living in the central portion of the reserve, as those remains could be from individuals occupying adjacent areas. Interaction between couples living in adjacent areas was reported by DiєTz (1984).

The higher percentages of remains found in the dry season may not reflect the pattern of the maned wolf activity in the reserve. Maned wolves from the Serra da Canastra National Park, monitored during a 20 month period by radiotelemetry, were active throughout the year, apparently showing greater activity during rainy and cloudy days than on sunny days (Dietz 1984). The author also observed that, during the day, the animals spent about 115 minutes moving around the areas occupied by them. However, they were more active at night with peak activity in its first half.

Sites containing more than one scat sample were identified in this study. These findings express aspects of the social interaction between the individuals (KLEIMAN 1972). In the Serra do Caraça Reserve, in addition to identifying sites of scat deposition apparently used by a mating pair, we also observed that male and female used the same trails. Tracks of an individual overlying those of another were often found, even though two animals moving together were not registered. When meat was being offered, the presence of a mating pair was common at the sanctuary. The animals appeared to have developed a significant degree of mutual tolerance while eating. However, after being fed, they frequently moved in different directions. In Serra da Canastra, Dietz (1984) observed adult individuals interacting on 25 occasions, with a significant overlapping of the areas used by the individuals. While our results do not represent the actual area occupied by the maned wolf in the Serra do Caraça Reserve, the total area obtained $\left(25.7 \mathrm{~km}^{2}\right)$, encompassing all remains, was similar to that estimated by DieTz (1984).

The spatial distribution pattern of the occurrences was central, rather than uniform over the entire area. Corroborating this was the proximity between the coordinates of the mean arithmetic centre and those of the mean harmonic centre, although the former tended to a displacement of the centre of activity, due to the location of the more distant occurrences (Dixon \& Chapman 1980). JennRich \& Turner (1969), estimating by the ellipse method the home range of squirrels, Sciurus vulgaris Linnaeus, 1758 , for $50 \%$ and $95 \%$ of the occurrences, observed that the coordinates of the arithmetic centre had no correspon- dence with the centre of activity of the animals, as the occurrences showed a non-aggregated distribution. Dixon \& CHAPMAN (1980), calculating the area of occupation of rabbits, Sylvilagus bachmani, (Waterhouse, 1838) found that the coordinates of the arithmetic centre corresponded to an area that was never used by the animals and that they had two distinct centres of activity. In the Serra do Caraça Reserve, the area more intensively used by the maned wolves, the core area comprised a small portion of the area encompassing all recorded remains. SPRINGER (1982), studying the movement pattern of coyotes, Canis latrans, (Say, 1823), also found a large number of grouped locations (83\%), corresponding to only $8.5 \%$ of the total home range of the individuals, this being attributed to the heterogeneous features of the area occupied by the animals. In the Serra do Caraça Reserve, the pattern of space utilization by the maned wolves, rather than being determined by the characteristics of the environment, was strongly influenced by the anthropic interference - the daily supply of meat - to which the animals were subjected. This interference was evidenced by the strong correlation found between the densities of the occurrences of remains and the mean distances from these to the sanctuary. Thus, human activities had a direct influence on the location of the centre of activity, as well on the size of the core area of these animals.

In spite of the low percentage of bead-marked scats found, the use of beads proved to be helpful in this study, as it allowed us to confirm that (1) the areas having a greater concentration of remains were effectively utilized by the maned wolves and (2) the area comprised by the bead-marked scats was similar to the core area of the animals. Therefore, bovine meat deliberately offered to the animals apparently makes it unnecessary for them to use a more extensive area. The size of the area occupied by the maned wolf in the Serra do Caraça Reserve may also be influenced by the region's topography, which is characterized by a rugged relief marked by abrupt elevations formed by quartzite rocks and the absence of large expands of flat areas that might favor the movement of the animals. Confirming this is the limitation of the core area in their northern portion, due to the presence of a forest and a very irregular relief.

The results reported here demonstrate that detailed information on area utilization by this species can be obtained using low-cost methods and techniques. Also, our findings stress the need for a better understanding of the effects of the supply of artificial foods on the behaviour of the maned wolf.

\section{ACKNOWLEDGEMENTS}

We thank H.P. Godinho, R. Young, F.D. Ávila-Pires, E.L.A. Monteiro-Filho and T.C. Cory, for critically reading the manuscript. J.E.C. Figueira and L. Barroso helped in statistical analyses. The Caraça Reserve keepers provided us with all facilities to study. Financial support was provided by FIP - PUC Minas and FAPEMIG. 


\section{REFERENCES}

Andrade, M.G. 2000. A educação exilada, Colégio do Caraça. Belo Horizonte, Editor Autêntica, 214p.

Adams, L. \& S.D. Davis. 1967. The internal anatomy of home range. Journal of Mammalogy, Lawrence, 48: 529-536.

Aragona, M. \& E.Z.F. Setz. 2001. Diet of maned wolf, Chrysocyon brachyurus (Mammalia: Canidae), during wet and dry seasons at Ibitipoca State Park, Brazil. Journal of Zoology, Londres, 254: 131-136.

BurT, W.H. 1943. Territoriality and home range concepts as applied to mammals. Journal of Mammalogy, Lawrence, 24: 346-352.

Childs, J. \& M. Colvin. 1998. Tracking the felids of the borderlands. El Paso, Corner press, 77p.

Crawshaw Jr., P.G. \& H.B. Quigley. 1989. Notes on ocelot movement e activity in the Pantanal, Brazil. Biotropica, Washington, D.C., 21: 301-307.

DiETz, J.M. 1984. Ecology and social organization of the maned wolf (Chrysocyon brachyurus). Smithsonian Contribution of Zoology, Washington, D.C., 392: 1-51.

Dixon, K.R. \& J.A. ChapMAn. 1980. Harmonic mean measure of animal activity areas. Ecology, Washington, D.C., 61: 10401044.

GeorgiI, B. 1980. Home range patterns of female red deer (Cervus elaphus) in the Alps. Oecologia, Heidelberg, 47: 278-285.

Givlietti, A.M. \& J.R. Pirani. 1988. Patterns of geographic distribution of some plant species from the Espinhaço Range, Minas Gerais and Bahia, Brazil, p. 39-69. In: P.E. VAnzolini \& W.R. Heyer (Eds). Proceedings of a workshop on Neotropical distribution patterns. Rio de Janeiro, Academia Brasileira de Ciências, 488p.

Giulietti, A.M.; J.R. Pirani \& R.M. Harley. 1997. Espinhaço Range region, Eastern Brazil, p. 397-404. In: S.D. Davis; V.H. Heywood; O. Herrera-MacBryde; J. Villa-Lobos \& A.C. HamilTON (Eds). Centres of plant diversity, a guide and strategy for their conservation. Oxford, Information Press, 562p.

Hayne, D.W. 1949. Calculation of size of home range. Journal of Mammalogy, Lawrence, 30: 1-18.

Hovey, F. 1999. Home range calculations. BC Forest Service, Research Branch, Revelstoke.

Inglis, J.M.; R.E. Hood; B.A. Brown \& C.A. Deyoung. 1979. Home range of white-tailed deer in Texas coastal prairie brushland. Journal of Mammalogy, Lawrence, 60: 377-389.

JeNnRICH, R.J. \& F.B. TuRnER. 1969. Measurement of non-circular home range. Journal of Theoretical Biology, Orlando, 22: 227-237.

KaUfmanN, J.H. 1962. Ecology and social behavior of the coati, Nasua narica on Barro Colorado Island Panama.
University of California Publications in Zoology 60: 95-222.

KLeIman, D.G. 1972. Social behavior of the maned wolf (Chrysocyon brachyurus) and bush dog (Speothos venaticus): a study in contrast. Journal of Mammalogy, Lawrence, 53: 791806.

KoneCNy, M.J. 1989. Movement patterns and food habitats of four sympatric carnivore species in Belize, Central America, In: K.H. REDFord \& J.F. EISENBERG (Eds). Advances in Neotropical Mammalogy, Gainesville, The Sandhill Crane Press, 243-264.

KRUUK, H. 1978. Spatial organization and territorial behavior of the European badger Meles meles. Journal of Zoology, London 184: 1-19.

MacDonald, D.W. \& O. Courtenay. 1996. Enduring social relationships in a population of crab-eating fox zorro, Cerdocyon thous, in Amazonian Brazil. Journal of Zoology, London 239: 329-355.

Metzgar, L.H. 1973. Home range shape and activity in Peromyscus leucopus. Journal of Mammalogy, Lawrence, 54: 383-390.

Moнr, C. 1947. Table of equivalent populations of North American small mammals. American Midland Naturalist, Notre Dame, 37: 223-249.

Randolf, S.E. 1977. Changing spatial relationships in a population of Apodemus sylvaticus with onset of breeding. Journal of Animal Ecology, Oxford, 46: 653-676.

SAMUEL, M.D. \& E.O. GARTON. 1987. Incorporating activity time in harmonic home range analysis. Journal of Wildlife Management, Bethusda, 51: 254-257.

Samuel, M.D., D.J. Pierce \& E.O. Garton. 1985. Identifying areas of concentrated use within the home range. Journal of Animal Ecology, Oxford, 54: 711-719.

Springer, J.T. 1982. Movement patterns of coyotes in south central Washington. Journal of Wildlife Management, Bethusda, 46: 191-200.

SWIHART, R.K. \& N.A. SLADE. 1985. Influence of sampling interval on estimates of home-range size. Journal of Wildlife Management, Bethusda, 49: 1019-1025.

TANAKA, R. 1980. Controversial problems in advanced research on estimating population densities of small rodents. Research Population Ecology Supplement, 2: 1-66.

Van Ballenberghe, V. \& J.M. Peek. 1971. Radiotelemetry studies of moose in northwestern Minnesota. Journal of Wildlife Management, Bethusda, 35: 63-71.

Worton, B.J. 1989. Kernel methods for estimating of homerange size. Biometrics, Arlington, 51: 1206-1215.

ZAR, J.H. 1999. Biostatistical Analysis. Upper Saddle River, Prentice-Hall, $4^{\text {th }}$ ed., 663p.

Received in 09.IX.2003; accepted in 09.VI.2004. 